\title{
Suicidality in Patients with Brain Tumors: A Brief Literature Review with Clinical Exemplar
}

\author{
Alessandra Costanza 1,2,*(D), Francesco Zenga ${ }^{3}\left(\mathbb{D}\right.$, Roberta Rudà 4 , Andrea Amerio ${ }^{5,6,7}$, \\ Andrea Aguglia ${ }^{5,6} \mathbb{D}^{\mathrm{D}}$, Gianluca Serafini ${ }^{5,6}{ }^{\mathbb{D}}$, Mario Amore ${ }^{5,6}$, Guido Bondolfi 1,8, \\ Isabella Berardelli 9 (D) and Khoa Dinh Nguyen $10,11,12$
}

1 Department of Psychiatry, Faculty of Medicine, University of Geneva (UNIGE), 1211 Geneva, Switzerland; guido.bondolfi@hcuge.ch

2 Department of Psychiatry, ASO Santi Antonio e Biagio e Cesare Arrigo Hospital, 15121 Alessandria, Italy

3 Department of Neurosurgery, University and City of Health and Science Hospital, 10126 Torino, Italy; zengafra@hotmail.com

4 Department of Neuro-Oncology, University and City of Health and Science Hospital, 10126 Torino, Italy; rudarob@hotmail.com

5 Department of Neuroscience, Rehabilitation, Ophthalmology, Genetics, Maternal and Child Health, Section of Psychiatry, University of Genoa, 16133 Genoa, Italy; andrea.amerio@unige.it (A.A.); andrea.aguglia@unige.it (A.A.); gianluca.serafini@unige.it (G.S.); mario.amore@unige.it (M.A.)

6 IRCCS Ospedale Policlinico San Martino, 16133 Genoa, Italy

7 Department of Psychiatry, Tufts University, Boston, MA 02111, USA

8 Department of Psychiatry, Service of Liaison Psychiatry and Crisis Intervention, Geneva University Hospitals, 1211 Geneva, Switzerland

9 Department of Neuroscience, Mental Health and Sensory Organs, Suicide Prevention Center, Sant'Andrea Hospital, Sapienza University of Rome, 00185 Rome, Italy; isabella.berardelli@uniroma1.it

10 Department of Microbiology and Immunology, Stanford University, Palo Alto, CA 94305, USA; khoa.d.nguyen@gmail.com

11 Tranquis Therapeutics, Palo Alto, CA 94305, USA

12 Hong Kong University of Science and Technology, Hong Kong, China

* Correspondence: alessandra.costanza@unige.ch

Received: 3 October 2020; Accepted: 19 December 2020; Published: 21 December 2020

\begin{abstract}
Background: Suicidality and brain tumors are two life-threatening conditions and, somewhat unexpectedly, the associations between them have scarcely been reported. Objective: In this study, we aimed to provide a brief literature review of epidemiological studies on suicidal ideation (SI) and suicidal behavior (SB) in patients with brain tumors. To illustrate various aspects of brain tumors that potentially underlie the emergence of suicidality, the review is supplemented with a clinical exemplar of a long-term survivor of brain tumor (glioblastoma) who experienced persistent SI. Furthermore, we discuss putative both neurobiological (including anatomical and immunological) and psychosocial mechanisms that might be accountable for the development of SI and SB in patients with brain tumors. Conclusions: While the etiology of this phenomenon appears to be multifactorial and still remains a subject of much debate, it is of critical importance to identify patients for which a psychiatric evaluation could recognize, in a timely manner, a possible suicide risk and alleviate the deep related suffering, by appropriate psychopharmacological and supportive and psychotherapeutic interventions.
\end{abstract}

Keywords: brain tumor; glioblastoma; glioma; suicide; suicidal ideation; suicide attempt; suicidal behavior; demoralization; meaning in life 


\section{Introduction}

Suicidality covers a host of phenomena, ranging from suicidal ideation (SI) to suicidal behaviors (SB), which include suicide attempts (SA), as well as completed suicide [1]. In spite of its seriousness, data on the prevalence of suicidality in individuals with a pre-existing illness [2-4], especially conditions with a neurological origin such as brain tumors, have not been frequently reported [5,6]. In this study, we provide a concise synthesis of the literature on this topic in order to summarize the reported frequency of SI and SB in patients with brain tumors. The review is also supplemented with a clinical case to illustrate different aspects of brain tumors that are potentially related to the development of suicidality. In the discussion, putative both neurobiological (including anatomical and immunological) and psychosocial disease mechanisms of these phenomena are highlighted [5].

\section{Brief Literature Review}

To date, few studies have investigated the association between suicidality and brain tumors (Table 1). The first incidence of suicidality in a patient with cerebral neuroblastoma was reported in 1989 [7]. Subsequently, a prospective analysis of 83 adult patients with glioma, astrocytoma, and meningioma revealed that approximately $14 \%$ exhibited SI [8], which is higher than the SI incidence in the general population ( 10.8\%) [9]. In contrast, Pranckeviciene et al., showed that only $5.7 \%$ of patients with high-grade glioma and meningioma reported SI [10]. These differences in suicidality rates of adult patients with brain tumors might reflect the heterogeneity of the studied participants with regard to the tumor types, as well as the suicidality assessment methods. In pediatric patients with brain tumors, the prevalence of suicidality appears to have been more thoroughly examined with the documentation of more than a 10-fold increase [11-13] over that of the general population $(\sim 0.6 \%)$ [14]. For instance, a study of pediatric patients with low grade glioma and embryonic tumors revealed that approximately $10.9 \%$ of patients reported SI or SA, or both [11]. Similarly, Recklitis et al., reported that $10.6 \%$ of 1136 pediatric patients exhibit symptoms of SI [12]. In another retrospective analysis of 60 pediatric patients with astrocytoma, SI was documented in 15\%, while SA was present in $3.3 \%$ of the participants [13]. In spite of discrepancies in the reported rates of SI and SA, these epidemiological studies highlight the emergence of suicidality in patients with brain tumors as a clinically important phenomenon that warrants further investigations into its pathogenesis in addition to risk factors.

In this regard, the case presented below is of particular interest, due to the development of persistent SI in spite of stable neoplastic disease. Additionally, the case presents some unusual characteristics, such as the rare occurrence of a post-actinic large-vessels occlusive vasculopathy after cerebral radiotherapy (which is primarily associated with small-vessel leukoencephalopathy) and the long survival of the patient (given that the histopathological diagnosis was of glioblastoma). Both of these features will be subsequently discussed among possible mechanistic determinants that are involved in the development of SI. 
Table 1. Epidemiologic data on the occurrence of suicidal ideation and behavior (SI and SB, respectively) in patients with brain tumors.

\begin{tabular}{|c|c|c|c|c|c|c|c|}
\hline \multirow{2}{*}{ Author } & \multirow{2}{*}{ Study Type } & \multicolumn{2}{|c|}{ Sample } & \multicolumn{4}{|c|}{ Disease Characteristics } \\
\hline & & Population & Size (N) & Histological Type & Anatomical Location & Assessment & Suicidality \\
\hline $\begin{array}{l}\text { Pranckeviciene et } \\
\text { al., 2016 [10] }\end{array}$ & Prospective & Adult & 211 & $\begin{array}{c}\text { Meningioma 39\% } \\
\text { High-grade glioma } 17 \%\end{array}$ & - & BDI-II & $5.7 \%$ of patients reported SI \\
\hline $\begin{array}{l}\text { Hickman et al., } \\
2016[8]\end{array}$ & Prospective & Adult & 83 & $\begin{array}{c}\text { Meningioma 32.5\% } \\
\text { Glioblastoma } 28.9 \% \\
\text { Astrocytoma } 7.2 \% \\
\text { Anaplastic Astrocytoma } 7.2 \%\end{array}$ & - & Survey & $\begin{array}{l}5 \text { patients indicated SI at more } \\
\text { than once } \\
7 \text { patients reported SI at least } \\
\text { once }\end{array}$ \\
\hline $\begin{array}{l}\text { Brinkman et al., } \\
2013 \text { [11] }\end{array}$ & Retrospective & Pediatric & 319 & $\begin{array}{l}\text { Low-grade glioma } 50.8 \% \\
\text { Embryonal tumor } 20.1 \%\end{array}$ & $\begin{array}{c}\text { Posterior fossa/cerebellum } \\
34.5 \% \\
\text { Diencephalon/brain stem 31\% } \\
\text { Cerebral cortex } 34.5 \%\end{array}$ & $\begin{array}{l}\text { DSM IV-TR based } \\
\text { interview }\end{array}$ & $\begin{array}{c}27 \text { patients reported SI } \\
3 \text { patients reported SI at more } \\
\text { than one screening } \\
5 \text { patients reported SA }\end{array}$ \\
\hline $\begin{array}{l}\text { Recklitis et al., } \\
2010[12]\end{array}$ & - & Pediatric & 1136 & - & - & BSI-18 & $10.6 \%$ of patients reported SI \\
\hline $\begin{array}{c}\text { Turner et al., } 2009 \\
\text { [13] }\end{array}$ & Retrospective & Pediatric & 60 & Astrocytoma 33\% & $\begin{array}{l}\text { Posterior fossa } 47 \% \\
\quad \text { Cortical } 33 \%\end{array}$ & $\begin{array}{l}\text { DSM IV-TR based } \\
\text { interview }\end{array}$ & $\begin{array}{l}9 \text { patients reported SI } \\
2 \text { patients reported SA }\end{array}$ \\
\hline
\end{tabular}

BDI = Beck Depression Inventory; BSI = Brief Symptom Inventory; DSM IV-TR = Diagnostic and Statistical Manual of Mental Disorders; SI = suicidal ideation; SA = suicide attempt 


\section{Clinical Case}

\subsection{Anamnestic Elements}

The patient was a married Caucasian woman who did not suffer from any major physical health problems or psychiatric illnesses (including depression or past experience of SI) before the onset of the brain tumor. She also did not have any family history of psychiatric illnesses. The patient was childless and worked as a primary school teacher. She was passionate about her work and well-respected by her colleagues. She also had a good support network of family members and friends and had no financial problems.

\subsection{History of Present Illness}

At the age of 38, the patient presented with a right partial motor seizure and secondary generalization and anomia (Figure 1). Subsequently, she underwent a macroscopically radical resection of a left frontoparietal glioblastoma, followed by external radiation with a total dose of $59.40 \mathrm{~Gy}$ delivered by a $6 \mathrm{MeV}$ linear accelerator. This regimen consists of $45 \mathrm{~Gy}$ via opposed parallel fields and a booster of $14.40 \mathrm{~Gy}$ via isocentric oblique fields in conventional fractionation. After the completion of radiotherapy, the patient received six cycles of procarbazine, lomustine, and vincristine (PCV) chemotherapy, resulting in a partial response of $80 \%$ reduction in the tumor mass. The residual tumor remained stable for 56 months. The patient was generally in good clinical condition until the onset of chief complaints, with the exception of anterograde memory deficits that prevented her from undertaking her professional activities as a teacher.

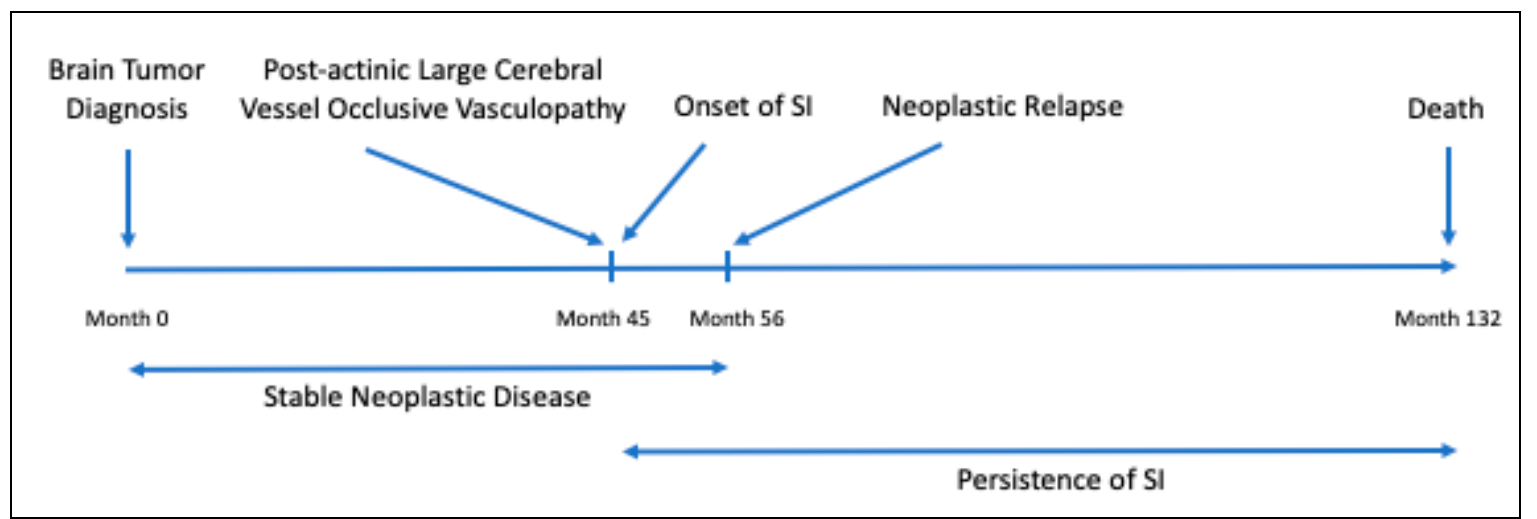

Figure 1. Development timeline of brain tumor and suicidal ideation (SI) in the reported clinical case. SI $=$ suicidal ideation.

\subsection{Chief Complaints}

Forty-five months after the completion of radiotherapy, the patient exhibited no signs of neoplastic relapse via enhanced magnetic resonance imaging (MRI). One day after this examination, the patient suddenly developed speech impairment and right brachial weakness that progressively extended to the right leg over the next three days. Concurrently, tacto-dolorific hypoesthesia and painful paresthesia developed.

This occasion marked the onset of pervasive SI. It was the first time the patient reported SI and this ideation persisted until the patient succumbed to neoplastic disease.

\subsection{Physical and Psychiatric Examination, Laboratory Investigation and Imaging Examinations}

A computerized tomography (CT) scan showed left cortical temporo-parietal hyperdensity. In the same area, an enhanced MRI revealed a widespread linear contrast enhancement along the cortical sulci ("gyral enhancement"), which indicated ischemia in the area which the middle cerebral artery 
divides into branches. A patient history and examinations performed during hospitalization were all negative for any general, hematological, and rheumatological risk factors for a large or medium vessel vasculopathy. Angiography did not show irregularities of the carotid and vertebra-basilar districts. Three weeks later, an MRI showed a notable tumor reduction in the pertinent areas, resulting in a nearly complete regression of the symptoms, except for mild residual aphasia. This "minor stroke" event was attributed to a radiation-induced large vessel vasculopathy due to the absence of the aforementioned risk factors and the restrictive nature of the ischemic location, which was mostly peritumoral and heavily irradiated.

Due to the onset of SI, the patient was evaluated by a psychiatrist. Diagnosis of depression was not established because of the absence of the Diagnostic and Statistical Manual of Mental Disorders; 5th edition (DSM-V) criteria. The patient was also assessed with the Montgomery-Åsberg Depression Rating Scale (MADRS) and Beck Depression Inventory-II Scale (BDI-II) $[15,16]$ to determine the presence and severity of depression. However, the scores on both of these scales confirmed the absence of clinically relevant depression. Item 9 of the BDI-II, concerning the presence of SI, was scored " 3 " ("I would commit suicide if I have a chance"). The severity of SI was not assessed more precisely by a specific scale. While SI was persistent, the patient did not exhibit any SB.

\subsection{Treatment of the Chief Complaints}

Since ischemia was not considered eligible for thrombolysis, acetylsalicylic acid $100 \mathrm{mg} / \mathrm{day}$ was initiated. Even in the absence of a diagnosis of depression, the psychiatrist empirically initiated a psychoparmachological treatment (sertraline $50 \mathrm{mg}$ /day with progressive increment to $100 \mathrm{mg} / \mathrm{day}$, alprazolam $0.25 \mathrm{mg} \times 3$ times a day, and olanzapine $2.5 \mathrm{mg} /$ day with progressive increment to $5 \mathrm{mg} / \mathrm{day}$ ) due to the presence of SI. The patient did not exhibit any psychotic symptoms. Olanzapine was introduced to potentiate the antidepressant action of sertraline, to reduce impulsivity (and possible transition to SB), and, as most suicidal patients describe, to alleviate specific deep anguish and "moral pain" associated with SI.

\subsection{Outcome and Follow-Up}

While the tumor remained stable for the next 11 months, a relapsing-remitting course of SI represented the most notable symptom even after psychopharmacological therapy, which induced no changes other than a moderate reduction in anguish and "moral pain" following the increase in olanzapine to $5 \mathrm{mg}$. Subsequently, the patient had a multicentric recurrence of the neoplastic disease and died 75 months after its incidence.

\section{Discussion}

While little is known about the etiology of suicidality in patients with brain tumors, observations from both epidemiological studies and the clinical exemplar mentioned above can provide important insights into the putative mechanisms of this phenomenon.

\subsection{Neurobiological Risk Factors for Suicidality in Brain Tumors}

The mechanistic linkage between suicidality and brain tumors could be attributed to various biological determinants of the tumors. For instance, the location of the tumors might have an important role in determining the risk for suicidality development. While suicide has been reported in sporadic cases of tumors of different nervous tissue origins [17-20], patients with lesions in the frontal lobe have a greater probability to develop SI [21-25]. Consistent with previous studies, the patient described in this report had a tumor in the left frontoparietal lobe, which was accompanied by SI. Such anatomical influence of the tumors might originate from the fact that their physical presence might directly impair the neuronal circuits that regulate SI and SB.

Alternatively, the histological subtype of the brain tumors might also influence the suicide risk. In support of this hypothesis, a systematic review of pediatric brain tumor survivors reported that 
SI was mostly associated with glioma [11,26]. Meningioma is another type of brain tumor that has been linked to increasing risk of SI development $[10,27]$. In line with this report, another study found that $21 \%$ of patients with benign meningioma presented with psychiatric symptoms; however, SI was not specifically investigated in these patients [7]. In spite of these findings, no clear evidence has suggested a causative association between brain tumor types and the development of suicidality. In fact, the patient in the current case and those reported by Ghaziuddin et al. [18], Nishio et al. [19], and Shehane et al. [20], had glioblastoma while others, reported by Arifin et al. [28] and Burris et al. [17], had meningioma and neurofibromatosis 1 , respectively.

Other than these intrinsic determinants, the brain tumor microenvironment might also influence the development of suicidality $[29,30]$. In this regard, brain tumors can trigger robust local inflammatory responses [31,32]. Systemic elevation of inflammatory markers has also been linked with worsening prognosis in patients with brain tumors [33,34]. Therefore, the presence of these inflammatory mediators in the circulation and cerebrospinal fluid (CSF) might potentiate the risk for suicidality as they have been convincingly shown to be positive correlates of SI. Notably, interleukin-6 (IL-6) levels are elevated in the CSF and peripheral blood, in addition to postmortem brain specimens of suicidal patients with brain tumors [35-37]. Such increases in IL-6 are also associated with violent and medically serious SA or future suicide completion [38,39]. Patients with SA also exhibit high levels of other inflammatory markers, such as interferon alpha and gamma (IFN- $\alpha,-\gamma)$ and tumors necrosis factor alpha (TNF- $\alpha)[38,40]$. It is worth noting that, besides these pathological inflammatory responses of the host to the tumors, brain tumor treatments, such as surgery and radiotherapy, could also elicit such events, and therefore further contribute to the risk of SI and SB in patients with brain tumors [41].

Last, but not least, the possible impact of vascular accidents induced by radiotherapy, including ischemic strokes, is of direct clinical relevance to the current case. While primarily chronic sequela resulting from cerebral radiotherapy is small-vessel leukoencephalopathy, this patient developed a rare post-actinic large-vessels occlusive vasculopathy. Corroborating studies have reported significant positive associations between stroke events and stroke-associated comorbidities and increasing risks of suicidality [42-46]. While the mechanisms of such events are likely to be closely related to the induction of neuroinflammatory responses during ischemic strokes [47], we did not find any evidence of neuroinflammation or systemic inflammation in the patient in this case. Such associations have not been reported in the literature, and would be of important interest for further investigations.

\subsection{Psychosocial Risk Factors for Suicidality in Brain Tumors}

In the context of nervous system tumors, the presence of psychosocial factors has been shown to be the strongest predictor of suicidality $[48,49]$. In this regard, evidence from this case report and previously published studies [8-14] suggest that SI in patients with brain tumors is linked to worsened quality of life, as the patients are constantly burdened by their unpredictable disease course and severe prognosis. Furthermore, psycho-behavioral and socioeconomic changes, such as feeling of impotence, financial distress, physical and mental disabilities, and loss of professional status, could develop. Collectively, these factors might aggravate the risk for neuropsychiatric illnesses, including suicidality. Increasing risk for the onset of SI during adulthood among pediatric survivors of brain tumors has also been reported [12,50]. Given the unexpectedly long survival of the patient affected by a glioblastoma presented in this case, the "survivor's guilt" might have developed and ultimately triggered SI $[12,50]$.

A number of psychological models have been investigated in our institution in the context of suicidality in patients with or without a co-morbid illness, such as the Interpersonal Theory of Suicide (IPTS) and "connectedness" [51-57]. Notably, the models that include "Meaning in Life" [58,59] and demoralization [60-63] constructs can be highly relevant to the phenomenon of suicidality in patients with brain tumors. According to a recent definition, "Meaning in Life" relates to one's perception of their own coherence, purpose, and significance [64] while demoralization has historically been described as "a persistent failure to cope with stresses" [65]. The latter has five constitutive 
sub-components, including loss of "Meaning in Life", hopelessness or disheartenment, helplessness, sense of failure, and dysphoria [66,67]. "Meaning in Life" and demoralization are closely and opposing linked, because meaninglessness is one of the sub-components of demoralization. These two constructs have been explored in individuals who suffer from extreme life situations, which expose them to an often incomprehensible fracture between "a before" and "an after". In particular, they have been investigated in oncologic illnesses and palliative cares [66-73]. Notably, "Meaning in Life" and demoralization can be employed to model the development of SI and SB in non-depressed patients $[66,67,74]$. In patients with cancers [68,75-78] and other medical diseases [79], demoralization and depression may frequently overlap; however, the former can occur independent of the latter.

In this particular case, loss of "Meaning in Life" and demoralization may offer a non-biological explanation for the development of depression-unrelated SI, because the patient never received a formal diagnosis of depression. We postulated that her depreciated "Meaning in Life" and demoralization might result from loss of status due to cancer-induced physical and mental impairments, which are key characteristics of patients with cancer [10]. In fact, loss of status as the basis for SI development was evident in this case as the patient was professionally incapacitated due to the occurrence of language and memory deficits. Moreover, the negative impact of the disease on her status was aggravated by the fact that she was childless and her existence revolved around her work with children. This observation is consistent with the notion that the presence of children has emerged as one of the most important factors that can give a "Meaning in Life" in suicidal patients [80].

\section{Conclusions}

This succinct review highlights suicidality as a serious psychiatric condition that may accompany brain tumors. Several mechanisms could be attributed to the development of this condition, including the neuroanatomical and neuroinflammation-related intrinsic features of the tumors and how they might alter physiological pathways that are indirectly involved in the development of suicidality in addition to psychosocial stresses that can directly trigger this suicidality. While the etiology of this phenomenon appears to be multifactorial and still remains a subject of much debate, it is of critical importance to identify patients for which a psychiatric evaluation could recognize in a timely manner a possible suicide risk and alleviate the deep related suffering, by appropriate psychopharmacological and supportive and psychotherapeutic interventions [81,82].

Author Contributions: Conceptualization, A.C., F.Z., and K.D.N.; First Draft Preparation, A.C., F.Z., and K.D.N.; Draft revision, A.A. (Andrea Amerio), A.A. (Andrea Aguglia) and R.R.; Supervision of all the work steps, G.S., M.A., G.B. and I.B. All authors have read and agreed to the published version of the manuscript.

Funding: This text received no specific grant from any funding agency in the public, commercial or not-for-profit sectors.

Acknowledgments: The authors gratefully acknowledge Riccardo Soffietti of the Neuro-Oncology Department at the University and City of Health and Science Hospital, Torino (Italy) for his crucial teaching and training, and Camila A. Suhett for her careful editing of the manuscript.

Conflicts of Interest: K.D.N. is the scientific founder of Tranquis Therapeutics, a neuroimmunology company that develops immunotherapies for neurological diseases. All the other authors report no conflict of interest.

\section{References}

1. Turecki, G.; Brent, D.A. Suicide and suicidal behaviour. Lancet 2016, 387, 1227-1239. [CrossRef]

2. Costanza, A.; Amerio, A.; Radomska, M.; Ambrosetti, J.; Di Marco, S.; Prelati, M.; Aguglia, A.; Serafini, G.; Amore, M.; Bondolfi, G.; et al. Suicidality Assessment of the Elderly with Physical Illness in the Emergency Department. Front. Psychiatry 2020, 11, 558974. [CrossRef] [PubMed]

3. Costanza, A.; Mazzola, V.; Radomska, M.; Amerio, A.; Aguglia, A.; Prada, P.; Bondolfi, G.; Sarasin, F.; Ambrosetti, J. Who Consult an Adult Psychiatric Emergency Department? Pertinence of Admissions and Opportunities for Telepsychiatry. Medicina (Kaunas) 2020, 56, 295. [CrossRef] [PubMed] 
4. Ostertag, L.; Golay, P.; Dorogi, Y.; Brovelli, S.; Bertran, M.; Cromec, I.; Van Der Vaeren, B.; Khan, R.; Costanza, A.; Wyss, K.; et al. The implementation and first insights of the French-speaking Swiss programme for monitoring self-harm. Swiss Med. Wkly. 2019, 149, w20016. [CrossRef] [PubMed]

5. Costanza, A.; Amerio, A.; Aguglia, A.; Escelsior, A.; Serafini, G.; Berardelli, I.; Pompili, M.; Amore, M. When Sick Brain and Hopelessness Meet: Some Aspects of Suicidality in the Neurological Patient. CNS Neurol. Disord. Drug Targets 2020, 19, 257-263. [CrossRef]

6. Costanza, A.; Baertschi, M.; Weber, K.; Canuto, A. Neurological diseases and suicide: From neurobiology to hopelessness. Rev. Med. Suisse 2015, 11, 402-405.

7. Wyche, M.; Stokes, B.A.; Shepherd, J.M.; Kakulas, B.A.; Ojeda, V.J. High-grade cerebral neuroblastoma: A case study. Med. J. Aust. 1989, 150, 505-507. [CrossRef]

8. Hickmann, A.K.; Nadji-Ohl, M.; Haug, M.; Hopf, N.J.; Ganslandt, O.; Giese, A.; Renovanz, M. Suicidal ideation, depression, and health-related quality of life in patients with benign and malignant brain tumors: A prospective observational study in 83 patients. Acta Neurochir. (Wien) 2016, 158, 1669-1682. [CrossRef] [PubMed]

9. Li, W.; Abbas, M.M.; Acharyya, S.; Ng, H.L.; Tay, K.Y.; Au, W.L.; Tan, L.C.S. Suicide in Parkinson's Disease. Mov. Disord. Clin. Pract. 2018, 5, 177-182. [CrossRef] [PubMed]

10. Pranckeviciene, A.; Tamasauskas, S.; Deltuva, V.P.; Bunevicius, R.; Tamasauskas, A.; Bunevicius, A. Suicidal ideation in patients undergoing brain tumor surgery: Prevalence and risk factors. Support Care Cancer 2016, 24, 2963-2970. [CrossRef] [PubMed]

11. Brinkman, T.M.; Liptak, C.C.; Delaney, B.L.; Chordas, C.A.; Muriel, A.C.; Manley, P.E. Suicide ideation in pediatric and adult survivors of childhood brain tumors. J. Neurooncol. 2013, 113, 425-432. [CrossRef] [PubMed]

12. Recklitis, C.J.; Diller, L.R.; Li, X.; Najita, J.; Robison, L.L.; Zeltzer, L. Suicide ideation in adult survivors of childhood cancer: A report from the Childhood Cancer Survivor Study. J. Clin. Oncol. 2010, 28, 655-661. [CrossRef] [PubMed]

13. Turner, C.D.; Chordas, C.A.; Liptak, C.C.; Rey-Casserly, C.; Delaney, B.L.; Ullrich, N.J.; Goumnerova, L.C.; Scott, R.M.; Begley, H.C.; Fletcher, W.J.; et al. Medical, psychological, cognitive and educational late-effects in pediatric low-grade glioma survivors treated with surgery only. Pediatr. Blood Cancer 2009, 53, 417-423. [CrossRef] [PubMed]

14. Dilillo, D.; Mauri, S.; Mantegazza, C.; Fabiano, V.; Mameli, C.; Zuccotti, G.V. Suicide in pediatrics: Epidemiology, risk factors, warning signs and the role of the pediatrician in detecting them. Ital. J. Pediatr. 2015, 41, 49. [CrossRef]

15. Williams, J.; Kobak, K. Development and reliability of a structured interview guide for the Montgomery-Åsberg Depression Rating Scale (SIGMA). Br. J. Psychiatry 2008, 192, 52-58. [CrossRef] [PubMed]

16. Bourque, P.; Beaudrette, D. Etude psychométrique du questionnaire de dépression de Beck auprès d'un échantillon d'étudiants universitaires francophones. Rev. Can. Des. Sci. Comport. 1982, 14, 211-218. [CrossRef]

17. Burris, C.K.H.; Stier, M.A.; Salamat, S.; Thomas, S.; Lauderdale, S.; Raven, M.L.; Rodriguez, M.E.; Reddy, D.N.; Potter, H.D.; Albert, D.M. Neurofibromatosis type 1: A neuro-psycho-cutaneous syndrome? Orbit 2018, 37, 208-211. [CrossRef]

18. Ghaziuddin, N.; DeQuardo, J.R.; Ghaziuddin, M.; King, C.A. Electroconvulsive treatment of a bipolar adolescent postcraniotomy for brain stem astrocytoma. J. Child Adolesc. Psychopharmacol. 1999, 9, 63-69. [CrossRef]

19. Nishio, S.; Morioka, T.; Fujii, K.; Inamura, T.; Fukui, M. Spinal cord gliomas: Management and outcome with reference to adjuvant therapy. J. Clin. Neurosci. 2000, 7, 20-23. [CrossRef]

20. Shehane, R.; Miller, S.; Suber, L.; Chakos, M. Treatment of Acute Psychosis with Second-Generation Antipsychotics in a Patient with Left Temporal Lobe Lesion. Case Rep. Psychiatry 2018, 2018, 9839252. [CrossRef]

21. Hawton, K.; van Heeringen, K. Suicide. Lancet 2009, 373, 1372-1381. [CrossRef]

22. Turecki, G.; Ernst, C.; Jollant, F.; Labonte, B.; Mechawar, N. The neurodevelopmental origins of suicidal behavior. Trends Neurosci. 2012, 35, 14-23. [CrossRef] [PubMed] 
23. Costanza, A.; D’Orta, I.; Perroud, N.; Burkhardt, S.; Malafosse, A.; Mangin, P.; La Harpe, R. Neurobiology of suicide: Do biomarkers exist? Int. J. Legal Med. 2014, 128, 73-82. [CrossRef] [PubMed]

24. Van Heeringen, K.; Mann, J.J. The neurobiology of suicide. Lancet Psychiatry 2014, 1, 63-72. [CrossRef]

25. Costanza, A.; Rothen, S.; Achab, S.; Thorens, G.; Baertschi, M.; Weber, K.; Canuto, A.; Richard-Lepouriel, H.; Perroud, N.; Zullino, D. Impulsivity and Impulsivity-Related Endophenotypes in Suicidal Patients with Substance Use Disorders: An Exploratory Study. Int. J. Ment. Health Addict. 2020. [CrossRef]

26. Shah, S.S.; Dellarole, A.; Peterson, E.C.; Bregy, A.; Komotar, R.; Harvey, P.D.; Elhammady, M.S. Long-term psychiatric outcomes in pediatric brain tumor survivors. Childs Nerv. Syst. 2015, 31, 653-663. [CrossRef] [PubMed]

27. Gupta, R.K.; Kumar, R. Benign brain tumours and psychiatric morbidity: A 5-years retrospective data analysis. Aust. N. Z. J. Psychiatry 2004, 38, 316-319. [CrossRef]

28. Arifin, M.Z.; Yudoyono, F.; Setiawan, C.; Sidabutar, R.; Sutiono, A.B.; Faried, A. Comprehensive management of frontal and cerebellar tumor patients with personality changes and suicidal tendencies. Surg. Neurol. Int. 2014, 5, 174. [CrossRef]

29. Serafini, G.; Parisi, V.M.; Aguglia, A.; Amerio, A.; Sampogna, G.; Fiorillo, A.; Pompili, M.; Amore, M. A Specific Inflammatory Profile Underlying Suicide Risk? Systematic Review of the Main Literature Findings. Int. J. Environ. Res. Public Health 2020, 17, 2393. [CrossRef]

30. Serafini, G.; Pompili, M.; Elena Seretti, M.; Stefani, H.; Palermo, M.; Coryell, W.; Girardi, P. The role of inflammatory cytokines in suicidal behavior: A systematic review. Eur. Neuropsychopharmacol. 2013, 23, 1672-1686. [CrossRef]

31. Mostofa, A.G.; Punganuru, S.R.; Madala, H.R.; Al-Obaide, M.; Srivenugopal, K.S. The Process and Regulatory Components of Inflammation in Brain Oncogenesis. Biomolecules 2017, 7, 34. [CrossRef] [PubMed]

32. Dzaye, O.; Hu, F.; Derkow, K.; Haage, V.; Euskirchen, P.; Harms, C.; Lehnardt, S.; Synowitz, M.; Wolf, S.A.; Kettenmann, H. Glioma Stem Cells but Not Bulk Glioma Cells Upregulate IL-6 Secretion in Microglia/Brain Macrophages via Toll-like Receptor 4 Signaling. J. Neuropathol. Exp. Neurol. 2016, 75, 429-440. [CrossRef] [PubMed]

33. Song, L.; Quan, X.; Su, L.; Wang, K.; Wang, H.; Wu, L.; Chen, C.; Li, S.; Xiang, W.; Chen, L.; et al. Inflammation and behavioral symptoms in preoperational glioma patients: Is depression, anxiety, and cognitive impairment related to markers of systemic inflammation? Brain Behav. 2020, e01771. [CrossRef]

34. Liang, R.; Li, J.; Tang, X.; Liu, Y. The prognostic role of preoperative systemic immune-inflammation index and albumin/globulin ratio in patients with newly diagnosed high-grade glioma. Clin. Neurol. Neurosurg. 2019, 184, 105397. [CrossRef] [PubMed]

35. O’Donovan, A.; Rush, G.; Hoatam, G.; Hughes, B.M.; McCrohan, A.; Kelleher, C.; O’Farrelly, C.; Malone, K.M. Suicidal ideation is associated with elevated inflammation in patients with major depressive disorder. Depress Anxiety 2013, 30, 307-314. [CrossRef]

36. Monje, F.J.; Cabatic, M.; Divisch, I.; Kim, E.J.; Herkner, K.R.; Binder, B.R.; Pollak, D.D. Constant darkness induces IL-6-dependent depression-like behavior through the NF-kappaB signaling pathway. J. Neurosci. 2011, 31, 9075-9083. [CrossRef]

37. Hoyo-Becerra, C.; Huebener, A.; Trippler, M.; Lutterbeck, M.; Liu, Z.J.; Truebner, K.; Bajanowski, T.; Gerken, G.; Hermann, D.M.; Schlaak, J.F. Concomitant interferon alpha stimulation and TLR3 activation induces neuronal expression of depression-related genes that are elevated in the brain of suicidal persons. PLoS ONE 2013,8, e83149. [CrossRef]

38. Gananca, L.; Oquendo, M.A.; Tyrka, A.R.; Cisneros-Trujillo, S.; Mann, J.J.; Sublette, M.E. The role of cytokines in the pathophysiology of suicidal behavior. Psychoneuroendocrinology 2016, 63, 296-310. [CrossRef]

39. Lindqvist, D.; Janelidze, S.; Hagell, P.; Erhardt, S.; Samuelsson, M.; Minthon, L.; Hansson, O.; Bjorkqvist, M.; Traskman-Bendz, L.; Brundin, L. Interleukin-6 is elevated in the cerebrospinal fluid of suicide attempters and related to symptom severity. Biol. Psychiatry 2009, 66, 287-292. [CrossRef]

40. Mina, V.A.; Lacerda-Pinheiro, S.F.; Maia, L.C.; Pinheiro, R.F., Jr.; Meireles, C.B.; de Souza, S.I.; Reis, A.O.; Bianco, B.; Rolim, M.L. The influence of inflammatory cytokines in physiopathology of suicidal behavior. J. Affect. Disord. 2015, 172, 219-230. [CrossRef]

41. Doron, H.; Pukrop, T.; Erez, N. A Blazing Landscape: Neuroinflammation Shapes Brain Metastasis. Cancer Res. 2019, 79, 423-436. [CrossRef] [PubMed] 
42. Fugate, J.E. Complications of Neurosurgery. Continuum (Minneap. Minn.) 2015, 21, 1425-1444. [CrossRef] [PubMed]

43. Pompili, M.; Venturini, P.; Campi, S.; Seretti, M.E.; Montebovi, F.; Lamis, D.A.; Serafini, G.; Amore, M.; Girardi, P. Do stroke patients have an increased risk of developing suicidal ideation or dying by suicide? An overview of the current literature. CNS Neurosci. Ther. 2012, 18, 711-721. [CrossRef] [PubMed]

44. Dou, J.; Tang, J.; Lu, C.H.; Jiang, E.S.; Wang, P.X. A study of suicidal ideation in acute ischemic stroke patients. Health Qual. Life Outcomes 2015, 13, 7. [CrossRef]

45. Yang, Y.; Shi, Y.Z.; Zhang, N.; Wang, S.; Ungvari, G.S.; Ng, C.H.; Wang, Y.L.; Zhao, X.Q.; Wang, Y.J.; Wang, C.X.; et al. Suicidal ideation at 1-year post-stroke: A nationwide survey in China. Gen. Hosp. Psychiatry 2017, 44, 38-42. [CrossRef]

46. Wu, V.C.; Chang, S.H.; Kuo, C.F.; Liu, J.R.; Chen, S.W.; Yeh, Y.H.; Luo, S.F.; See, L.C. Suicide death rates in patients with cardiovascular diseases-A 15-year nationwide cohort study in Taiwan. J. Affect. Disord. 2018, 238, 187-193. [CrossRef]

47. Maida, C.D.; Norrito, R.L.; Daidone, M.; Tuttolomondo, A.; Pinto, A. Neuroinflammatory Mechanisms in Ischemic Stroke: Focus on Cardioembolic Stroke, Background, and Therapeutic Approaches. Int. J. Mol. Sci. 2020, 21, 6454. [CrossRef]

48. Smailyte, G.; Jasilionis, D.; Kaceniene, A.; Krilaviciute, A.; Ambrozaitiene, D.; Stankuniene, V. Suicides among cancer patients in Lithuania: A population-based census-linked study. Cancer Epidemiol. 2013, 37, 714-718. [CrossRef]

49. Spoletini, I.; Gianni, W.; Caltagirone, C.; Madaio, R.; Repetto, L.; Spalletta, G. Suicide and cancer: Where do we go from here? Crit. Rev. Oncol. Hematol. 2011, 78, 206-219. [CrossRef]

50. Massetti, G.M.; Holland, K.M.; Jack, S.P.D.; Ragan, K.R.; Lunsford, N.B. Circumstances of suicide among individuals with a history of cancer. Psychooncology 2018, 27, 1750-1756. [CrossRef]

51. Baertschi, M.; Costanza, A.; Canuto, A.; Weber, K. The Function of Personality in Suicidal Ideation from the Perspective of the Interpersonal-Psychological Theory of Suicide. Int. J. Environ. Res. Public Health 2018, 15, 636. [CrossRef] [PubMed]

52. Baertschi, M.; Costanza, A.; Canuto, A.; Weber, K. The dimensionality of suicidal ideation and its clinical implications. Int. J. Methods Psychiatr. Res. 2019, 28, e1755. [CrossRef] [PubMed]

53. Baertschi, M.; Costanza, A.; Richard-Lepouriel, H.; Pompili, M.; Sarasin, F.; Weber, K.; Canuto, A. The application of the interpersonal-psychological theory of suicide to a sample of Swiss patients attending a psychiatric emergency department for a non-lethal suicidal event. J. Affect. Disord. 2017, 210, 323-331. [CrossRef] [PubMed]

54. Costanza, A.; Ambrosetti, J.; Wyss, K.; Bondolfi, G.; Sarasin, F.; Khan, R. [Prevention of suicide at Emergency Room: From the $<<$ Interpersonal Theory of Suicide $>>$ to the connectedness]. Rev. Med. Suisse 2018, 14, 335-338. [PubMed]

55. Van Orden, K.A.; Witte, T.K.; Cukrowicz, K.C.; Braithwaite, S.R.; Selby, E.A.; Joiner, T.E., Jr. The interpersonal theory of suicide. Psychol. Rev. 2010, 117, 575-600. [CrossRef] [PubMed]

56. Joiner, T.E. Why People Die by Suicide; Harvard University Press: Cambridge, UK, 2005.

57. Costanza, A.; Amerio, A.; Aguglia, A.; Serafini, G.; Amore, M. Meaning in Life and Demoralization Constructs in Light of the Interpersonal Theory of Suicide: A Trans-Theoretical Hypothesis for a Cross-Sectional Study. Psychol. Res. Behav. Manag. 2020, 13, 855-858. [CrossRef]

58. Costanza, A.; Baertschi, M.; Richard-Lepouriel, H.; Weber, K.; Pompili, M.; Canuto, A. The Presence and the Search Constructs of Meaning in Life in Suicidal Patients Attending a Psychiatric Emergency Department. Front. Psychiatry 2020, 11, 327. [CrossRef]

59. Costanza, A.; Prelati, M.; Pompili, M. The Meaning in Life in Suicidal Patients: The Presence and the Search for Constructs. A Systematic Review. Medicina (Kaunas) 2019, 55, 465. [CrossRef]

60. Chytas, V.; Costanza, A.; Piguet, V.; Cedraschi, C.; Bondolfi, G. [Demoralization and meaning in life in suicidal ideation: A role for patients suffering from chronic pain?]. Rev. Med. Suisse 2019, 15, 1282-1285.

61. Costanza, A.; Baertschi, M.; Richard-Lepouriel, H.; Weber, K.; Berardelli, I.; Pompili, M.; Canuto, A. Demoralization and Its Relationship with Depression and Hopelessness in Suicidal Patients Attending an Emergency Department. Int. J. Environ Res. Public Health 2020, 17, 2232. [CrossRef] 
62. Costanza, A.; Di Marco, S.; Burroni, M.; Corasaniti, F.; Santinon, P.; Prelati, M.; Chytas, V.; Cedraschi, C.; Ambrosetti, J. Meaning in life and demoralization: A mental-health reading perspective of suicidality in the time of COVID-19. Acta Biomed. 2020, in press.

63. Costanza, A.; Chytas, V.; Mazzola, V.; Piguet, V.; Desmeules, J.; Bondolfi, G.; Cedraschi, C. The Role of Demoralization and Meaning in Life (DEMiL) in Influencing Suicidal Ideation Among Patients Affected by Chronic Pain: Protocol of a Single-Center, Observational, Case-Control Study. JMIR Res. Protoc. 2020, 9, e24882. [CrossRef] [PubMed]

64. Martela, F.; Ryan, R.M. The Benefits of Benevolence: Basic Psychological Needs, Beneficence, and the Enhancement of Well-Being. J. Personal. 2016, 84, 750-764. [CrossRef] [PubMed]

65. Frank, J.D. Psychotherapy: The restoration of morale. Am. J. Psychiatry 1974, 131, 271-274. [CrossRef] [PubMed]

66. Kissane, D.W.; Clarke, D.M.; Street, A.F. Demoralization syndrome-A relevant psychiatric diagnosis for palliative care. J. Palliat. Care 2001, 17, 12-21. [CrossRef]

67. Clarke, D.M.; Kissane, D.W. Demoralization: Its phenomenology and importance. Aust. N. Z. J. Psychiatry 2002, 36, 733-742. [CrossRef]

68. Fang, C.K.; Chang, M.C.; Chen, P.J.; Lin, C.C.; Chen, G.S.; Lin, J.; Hsieh, R.K.; Chang, Y.F.; Chen, H.W.; $\mathrm{Wu}, \mathrm{C} . \mathrm{L}$.; et al. A correlational study of suicidal ideation with psychological distress, depression, and demoralization in patients with cancer. Support Care Cancer 2014, 22, 3165-3174. [CrossRef]

69. Vehling, S.; Kissane, D.W.; Lo, C.; Glaesmer, H.; Hartung, T.J.; Rodin, G.; Mehnert, A. The association of demoralization with mental disorders and suicidal ideation in patients with cancer. Cancer 2017, 123, 3394-3401. [CrossRef]

70. Robinson, S.; Kissane, D.W.; Brooker, J.; Hempton, C.; Burney, S. The Relationship Between Poor Quality of Life and Desire to Hasten Death: A Multiple Mediation Model Examining the Contributions of Depression, Demoralization, Loss of Control, and Low Self-worth. J. Pain Symptom Manag. 2017, 53, 243-249. [CrossRef]

71. Nanni, M.G.; Caruso, R.; Travado, L.; Ventura, C.; Palma, A.; Berardi, A.M.; Meggiolaro, E.; Ruffilli, F.; Martins, C.; Kissane, D.; et al. Relationship of demoralization with anxiety, depression, and quality of life: A Southern European study of Italian and Portuguese cancer patients. Psychooncology 2018, 27, 2616-2622. [CrossRef]

72. Xu, K.; Hu, D.; Liu, Y.; Han, Y.; Guo, X.; Teng, F.; Zhou, Y. Relationship of Suicidal Ideation With Demoralization, Depression, and Anxiety: A Study of Cancer Patients in Mainland China. J. Nerv. Ment. Dis. 2019, 207, 326-332. [CrossRef] [PubMed]

73. Liu, S.T.; Wu, X.; Wang, N.; Zhao, Q.Q.; Xiao, L.; Fang, C.K.; Yu, Y.; Lin, D.M.; Zhang, L.L. Serial multiple mediation of demoralization and depression in the relationship between hopelessness and suicidal ideation. Psychooncology 2020, 29, 1321-1328. [CrossRef] [PubMed]

74. Figueiredo, J.M.D. Distress, demoralization and psychopathology: Diagnostic boundaries. Eur. J. Psychiatry 2013, 27, 61-73. [CrossRef]

75. Angelino, A.F.; Treisman, G.J. Major depression and demoralization in cancer patients: Diagnostic and treatment considerations. Support Care Cancer 2001, 9, 344-349. [CrossRef] [PubMed]

76. Jacobsen, J.; Vanderwerker, L.; Block, S.; Friedlander, R.; Maciejewski, P.; Prigerson, H. Depression and demoralization as distinct syndromes: Preliminary data from a cohort of advanced cancer patients. Indian J. Palliat. Care 2006, 12, 8-15. [CrossRef]

77. Kissane, D.W.; Wein, S.; Love, A.; Lee, X.Q.; Kee, P.L.; Clarke, D.M. The Demoralization Scale: A report of its development and preliminary validation. J. Palliat. Care 2004, 20, 269-276. [CrossRef] [PubMed]

78. Tang, P.L.; Wang, H.H.; Chou, F.H. A Systematic Review and Meta-Analysis of Demoralization and Depression in Patients With Cancer. Psychosomatics 2015, 56, 634-643. [CrossRef]

79. Mangelli, L.; Fava, G.A.; Grandi, S.; Grassi, L.; Ottolini, F.; Porcelli, P.; Rafanelli, C.; Rigatelli, M.; Sonino, N. Assessing demoralization and depression in the setting of medical disease. J. Clin. Psychiatry 2005, 66, 391-394. [CrossRef]

80. Costanza, A.; Amerio, A.; Odone, A.; Baertschi, M.; Richard-Lepouriel, H.; Weber, K.; Di Marco, S.; Prelati, M.; Aguglia, A.; Escelsior, A.; et al. Suicide prevention from a public health perspective. What makes life meaningful? The opinion of some suicidal patients. Acta Biomed. 2020, 91, 128-134. [CrossRef]

81. Amerio, A.; Sibilla, F.; Pescini, R.; Ciprandi, R.; Casciaro, R.; Grimaldi Filioli, P.; Porcelli, C.; Odone, A.; Costanza, A.; Aguglia, A.; et al. Mental health and cystic fibrosis: Time to move from secondary prevention to predictive medicine. Pediatr. Pulmonol. 2020, 55, 2204-2206. [CrossRef] 
82. Leung, Y.W.; Li, M.; Devins, G.; Zimmermann, C.; Rydall, A.; Lo, C.; Rodin, G. Routine screening for suicidal intention in patients with cancer. Psychooncology 2013, 22, 2537-2545. [CrossRef] [PubMed]

Publisher's Note: MDPI stays neutral with regard to jurisdictional claims in published maps and institutional affiliations.

(C) 2020 by the authors. Licensee MDPI, Basel, Switzerland. This article is an open access article distributed under the terms and conditions of the Creative Commons Attribution (CC BY) license (http://creativecommons.org/licenses/by/4.0/). 